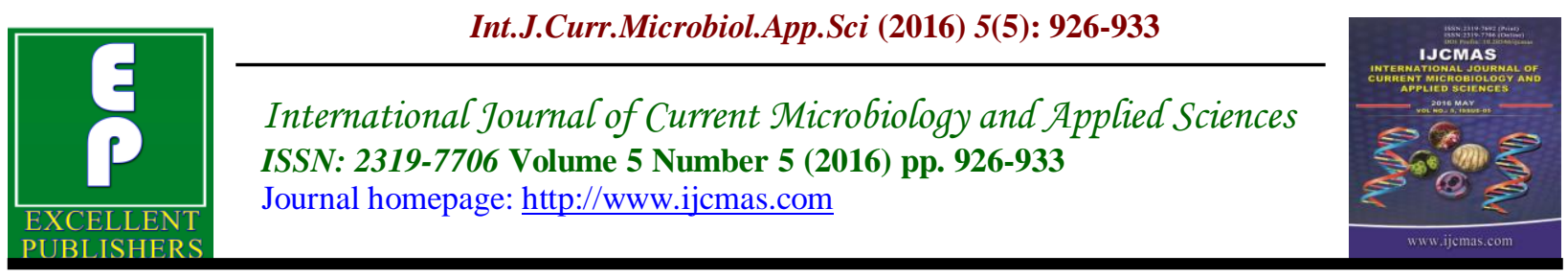

Original Research Article

http://dx.doi.org/10.20546/ijcmas.2016.505.097

\title{
Isolation and Characterization of Lipase Producing Bacteria from Windrow Compost
}

\author{
V.P. Shaini ${ }^{1}$ and S. Jayasree ${ }^{2 *}$ \\ ${ }^{1}$ Research and Development Centre, Bharathiar University, Coimbatore, TamilNadu, India \\ ${ }^{2}$ Department of Zoology, Mercy College, Palakkad, Kerala-678006, India \\ *Corresponding author
}

\begin{abstract}
A B S T R A C T
Keywords

Windrow

compost,

Lipase,

Staphylococcus,

Pseudomonas,

ABIS online.

\section{Article Info}

Accepted:

12 April 2016

Available Online:

10 May 2016

Lipolytic enzymes are currently attracting significant attention because of their biotechnological potential. Most of the lipases used in industry are microbial enzymes, of both fungal and bacterial origin. Windrow composting is a controlled, self-heating, aerobic degradation of organic materials by mesophilic and thermophilic microorganisms. The present study deals with isolation of lipase producing bacteria from windrow compost. The samples were collected from compost heap at an interval of 10 days and screened for lipase producing bacterial fauna in Tributyrin agar medium after serial dilution. A clear zone of hydrolysis indicated enzyme production. Out of 73 bacterial colonies screened, 24 lipase producing bacterial strains were isolated by checking the production of zone clearance in the tributyrin agar medium. Based on the morphological and biochemical characteristics 24 bacterial strains were identified up to species levels with the help of ABIS online analysis tool. The best lipase producers Staphylococcus $\left(\mathrm{WCS}_{1} \mathrm{C}_{2}\right)$ and Pseudomonas $\left(\mathrm{WCS}_{3} \mathrm{C}_{2}\right)$ genus were further characterized by $16 \mathrm{~s}$ rDNA sequencing and identified as Staphylococcus saprophytics and Pseudomonas otidis. These bacterial strains can be used for the production of lipase enzyme for industrial applications.
\end{abstract}

\section{Introduction}

Lipases (EC3.1.3), known as triacylglycerol acyhydrolases, are capable of catalyzing hydrolysis of long chain triacylglycerides into free fatty acids and glycerols in aqueous solutions and conducting synthetic reaction in organic media( Masomian et. al., 2013). Most commercially useful lipases are of microbial origin. Due to commercial importance of extracellular lipases, many microorganisms have been studied for their lipase production ability (Maia et. al., 2001).
Lipase producing microorganisms have been found in diverse habitats such as industrial wastes, vegetable oil processing factories, soil contaminated with oil, oil seeds and decaying food, compost heaps ,coal tips and hot springs( Wang et al., 1995)

The major share of industrial enzyme market is occupied by hydrolytic enzymes, such as protease, amylase, esterase, and lipase. Among these hydrolytic enzymes like 
lipases furnish the greatest share in the industrial enzyme market. In wake of recent advancements in microbiology and biotechnology, lipases have emerged as key enzymes owing to their multifaceted properties which find use in a wide array of industrial applications (Benjamin and Pandey, 1996; Jaeger et.al., 1994).

Lipase have been isolated and purified from fungi, yeast, bacteria, plant and animal sources but bacterial lipases are more economical and stable (Snellmanet et. al., 2002). Bacterial lipases are extensively used in food and dairy industry, cheese ripening, flavour enhancement (Falch, 1991), detergent industry (Fujii et. al., 1986), textile industry (Sharma et. al 2001), for synthesis of biodegradable polymers or compounds

(Linko et. al., 1998), different transesterification reactions ( Hasan, et al., 2006), cosmetic industry ( Seitz,1974), in pulp and paper industry (Bajpai, 1999), in synthesis of biodiesel (Noureddini et. al., 2005), and in pharmaceutical industries (Higaki, and Morohashi 2003). Currently bacterial lipases are of great demand because of potential industrial applications (Sirisha et al., 2010).

Considering the ever increasing demand for the better lipases in the industry for the search for ecofriendly and economical sources of lipase producing bacteria the present study has been carried out to isolate and characterize the novel lipase producing bacteria from windrow compost.

\section{Materials and Methods}

\section{Preparation of Compost Bed}

Windrow compost was done in solid waste management unit of Mercy college campus. The compost bed was prepared by using garden wastes and kitchen waste generated at Mercy college campus. Solid waste and cow dung inoculums in the ratio 10: 1 is spread in alternative layers, forming a windrow. The height of the heap is kept up to 1.5 and the moisture content is maintained at $50-60 \%$ during the composting. The waste was turned in the different sections of the windrow unit at 5- day intervals for 60 days. The windrow was covered with High Density poly Ethylene sheet silpaulin to protect from scavengers and to maintain required temperature of $60-70^{\circ} \mathrm{c}$ avoiding heat dissipation. The bed is regularly monitored and proper aeration and agitation is provided. (Jayasree and Ranjini, 2012)

\section{Collection of the Compost Sample}

Compost samples were collected at an interval of 10 days for about six turns. About $10 \mathrm{~g}$ of soil samples were collected using a sterile spatula in a sterile beaker. Temperature and $\mathrm{pH}$ of the sample were recorded.

\section{Screening of Lipolytic Bacterial Strains}

Serial dilutions of the samples were made up to $10^{-7}$ and each dilution were pour plated using Tributyrin agar media and the plates were incubated at $37^{\circ} \mathrm{C}$ for 24,48 and 72 hours. The morphological characteristics of the colonies were observed and the colonies with zone of clearance were selected (Sirisha et al., 2010). The diameter of the zone of clearance was noted at 24,48 , and 72 hours. The colonies with one of clearance were inoculated into nutrient broth and stored for further characterization.

\section{Phenotypic Identification}

Phenotypic identification of lipase producing bacteria was characterized via conventional morphological observation (Barrow and Feltham, 1993). 


\section{Biochemical Characterization}

The isolated positive colonies were identified by biochemical analysis following the methods described in Bergey's manual of systemic bacteriology (Claus and Berkeley, 2011). Gram staining reaction, biochemical tests like catalase test, oxidase test ,indole production, methyl production test, vogues proskauer test, citrate utilization test, macconkey agar test, mannitol salt agar, motility test, $\mathrm{H}_{2} \mathrm{~S}$ Production test, urease test, potassium hydroxide test, acetate utilization test, lactose fermentation test, starch hydrolysis test, gelatin hydrolysis test and nitrate reduction tests were done as per the procedure described in Bergey's manual.

\section{Lipolytic Activity Assay}

Lypolytic activity assay was detected by screening zone of hydrolysis around colonies growing on a solid basal T BA medium (peptone $5 \mathrm{~g}$, beef extract $3 \mathrm{~g}$, tributyrin $10 \mathrm{ml}$ and agar $20 \mathrm{~g}$. The medium was prepared in distilled water and $\mathrm{pH}$ 7.2) All of the isolates were inoculated for lipolytic activity and were incubated at $37^{\circ} \mathrm{C}$ for $24 \mathrm{hrs}$. Lipolytic activity of the isolates was detected by appearance of an opaque zone around the colonies. Total halo diameter, minus the diameter of the colony was considered to be proportional to the lipolytic activity (Jaeger, 1994).

\section{Identification of Isolated Bacterium}

Lipolytic bacterial isolates were identified up to the species level by ABIS online software. The two highest lipase producers were further characterized by $16 \mathrm{~s}$ rDNA sequencing. 16SrDNA fragment was amplified by PCR from bacterial genomic DNA using 16S rDNA universal primers: The primers used for the forward and backward reaction are : 8F: 5'-AGAGTTTGATCMTGG-3'
1492R: 5'-ACCTTGTTACGACTT-3'

PCR was carried out in a final reaction volume of $25 \mu \mathrm{l}$ in $200 \mu \mathrm{l}$ capacity thin wall PCR tube. PCR tubes containing the mixture were tapped gently and spin briefly at $10,000 \mathrm{rpm}$. The PCR tubes with all the components were transferred to thermal cycler. The PCR protocol designed for 30 cycles for the primers used for 16SrDNA amplification.

\section{Results and Discussion}

Out of 73 bacterial colonies screened, 24 bacterial strains were identified with the help of ABIS online software after submitting the results of various biochemical tests as lipase producers (Tembhurkar et al., 2012). Several workers studied the qualitative lipolytic activity in bacterial isolates and determined it on tributyrin containing agar plates (Jaeger et al., 1999 and Kim, et al., 2002).

Screening of lipase producers on agar plates using tributyrin is usually favored as the substrate in plate assay technique has been reported (Brockerhoff and Jensen, 1974). In this study the isolates $\mathrm{WCS}_{1} \mathrm{C}_{2}, \mathrm{WCS}_{3} \mathrm{C}_{2}$, $\mathrm{WCS}_{5} \mathrm{C}_{1}, \mathrm{WCS}_{5} \mathrm{C}_{3}, \mathrm{WCS}_{6} \mathrm{C}_{4}$ and $\mathrm{WCS}_{6} \mathrm{C}_{3}$ showed significant lipolytic activity on tributyrin agar plates (Fig.1, 2,)similar studies of Patcha and Wiyada., 2013. The 24 isolates identified by morphological and biochemical characteristics were tabulated in (Table1,2)(Claus and Berkeley, 2011). Pseudomonas spp and chromobacterium spp have been well exploited for lipase production (Ghosh et at., 1996). Among bacterial lipases, attention has usually been focused on particular classes of enzymes such as the lipases from the genus Pseudomonas, which are especially interesting for biotechnology (Gilbert, 1993). 
Table.1 Morphological Characteristics of Dominant Bacteria in the Windrow Compost

\begin{tabular}{|l|l|l|l|l|}
\hline Samples & Appearance & Margin & Elevation & Colour \\
\hline WCS1-C1 & Round,L-Form & Smooth & Convex & Cream \\
\hline WCS1-C2 & L-Form & Smooth & Convex & Cream \\
\hline WCS1-C3 & Round & Smooth & Convex & Cream \\
\hline WCS2-C1 & Round & Smooth & Convex & Cream \\
\hline WCS2-C2 & Raised & Wavy & Wavy,Convex & Cream \\
\hline WCS2-C3 & Irregular Spreading & Wavy,Smooth & Convex & Cream \\
\hline WCS2-C4 & L-Form & Smooth & Convex & Cream \\
\hline WCS2-C5 & Round & Smooth,Wavy & Transluscent,Wavy & Cream \\
\hline WCS3-C1 & L-Form & Smooth & Convex & Cream \\
\hline WCS3-C2 & Round,L-Form & Smooth,Wavy & Wavy,Convex & Cream \\
\hline WCS3-C3 & Round,Rhizoid & Smooth,Branching & Convex,Flat & Cream \\
\hline WCS3-C4 & Round & Smooth & Convex & Cream \\
\hline WCS4-C1 & Rhizoid & Branching & Flat & Cream \\
\hline WCS4-C2 & Round,L-Form & Smooth & Convex & Cream \\
\hline WCS4-C3 & Round & Smooth & Convex & Cream \\
\hline WCS4-C4 & L-Form & Smooth & Convex & Cream \\
\hline WCS4-C5 & Round,L-Form & Smooth,Wavy & Convex & Cream \\
\hline WCS5-C1 & L-Form & Smooth & Convex & Yellowish \\
\hline WCS5-C2 & Raised & Wavy & Wavy,Convex & Cream \\
\hline WCS5-C3 & Round & Smooth,Wavy & Convex,Wavy & Cream \\
\hline WCS6-C1 & Irregular Spreading & Smooth,Wavy & Convex & Cream \\
\hline WCS6-C2 & Round & Smooth & Convex & Cream \\
\hline WCS6-C3 & Round,L-Form & Smooth & Convex & Cream \\
\hline WCS6-C4 & L-Form & Smooth & Convex & Cream \\
\hline
\end{tabular}

Fig.1 TBA Plates with Highest Lipase Producing Bacterial Isolates

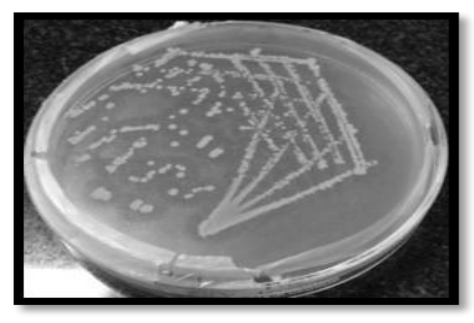

$\mathrm{WCS}_{1} \mathrm{C}_{2}$

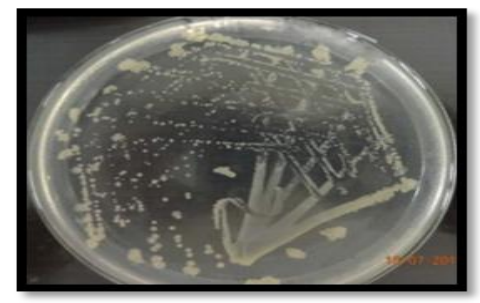

$\mathrm{WCS}_{5} \mathrm{C}_{3}$

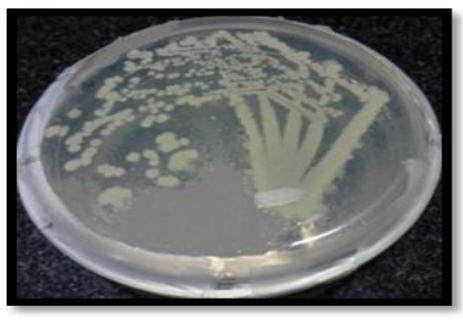

$\mathrm{WCS}_{3} \mathrm{C}_{2}$

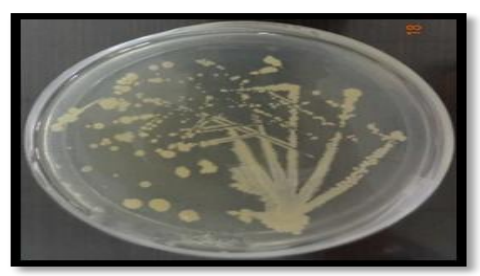

$\mathrm{WCS}_{6} \mathrm{C}_{4}$

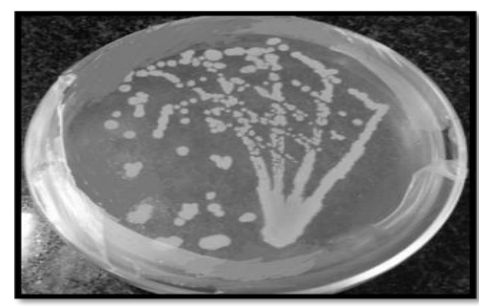

$\mathrm{WCS}_{5} \mathrm{C}_{1}$

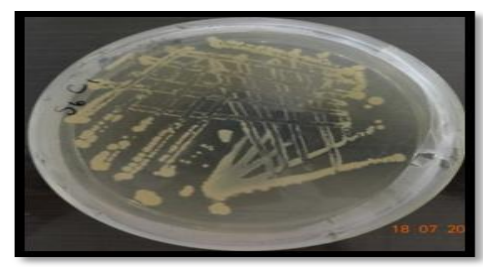

$\mathrm{WCS}_{6} \mathrm{C}_{3}$ 
Table.2 Physiological and Biochemical Characteristics of Dominant Bacteria in the Windrow Compost

\begin{tabular}{|c|c|c|c|c|c|c|c|c|c|c|c|c|c|c|c|c|c|c|c|}
\hline $\begin{array}{l}\text { Windrow } \\
\text { compost }\end{array}$ & $\begin{array}{l}\mathbf{G} \\
\mathbf{R}\end{array}$ & $\begin{array}{l}\mathbf{C} \\
\mathbf{T}\end{array}$ & $\begin{array}{l}\mathbf{O} \\
\mathbf{T}\end{array}$ & $\begin{array}{l}\mathbf{I} \\
\mathbf{P}\end{array}$ & $\begin{array}{l}\mathbf{M} \\
\mathbf{R}\end{array}$ & $\begin{array}{l}\mathbf{V} \\
\mathbf{P}\end{array}$ & $\begin{array}{l}\mathbf{C} \\
\mathbf{U}\end{array}$ & $\begin{array}{l}\mathbf{M} \\
\mathbf{C}\end{array}$ & $\begin{array}{l}\mathbf{M} \\
\mathbf{L}\end{array}$ & $\begin{array}{l}\mathbf{M} \\
\mathbf{T}\end{array}$ & $\begin{array}{l}\mathbf{H} \\
\mathbf{P}\end{array}$ & $\begin{array}{l}\mathbf{U} \\
\mathbf{T}\end{array}$ & $\mathbf{K}$ & $\begin{array}{l}\mathbf{A} \\
\mathbf{U} \\
\mathbf{T}\end{array}$ & $\begin{array}{l}\mathbf{L} \\
\mathbf{F}\end{array}$ & $\begin{array}{l}\mathbf{S} \\
\mathbf{H}\end{array}$ & $\mathbf{G}$ & $\begin{array}{l}\mathbf{N} \\
\mathbf{R T}\end{array}$ & Probable organisms \\
\hline WCS1-C1 & - & + & - & - & - & - & - & - & - & - & - & + & - & - & - & - & + & + & Pseudomonas aerogenosa \\
\hline WCS1-C2 & + & + & - & - & - & - & - & - & - & - & - & + & - & - & - & - & & + & $\begin{array}{l}\text { Staphylococcus } \\
\text { saprophyticus }\end{array}$ \\
\hline WCS1-C3 & + & + & + & - & - & + & - & - & - & + & - & + & - & - & - & - & - & + & Streptococcus \\
\hline WCS2-C1 & - & + & + & - & - & + & - & - & + & - & - & + & - & - & - & - & + & + & Actinobacillus scotiae \\
\hline WCS2-C2 & - & - & - & - & - & + & - & + & + & + & - & + & - & + & + & - & 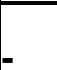 & + & Klebsiella pneumoniae \\
\hline WCS2-C3 & - & + & - & - & - & + & - & - & - & - & - & + & - & - & - & - & + & - & Bacillus niacini \\
\hline WCS2-C4 & - & + & + & - & - & + & - & + & - & - & - & + & - & - & + & - & + & + & $\begin{array}{l}\text { Yersinia } \\
\text { pseudotuberculosis }\end{array}$ \\
\hline WCS2-C5 & + & + & - & - & - & - & - & + & - & + & - & - & - & - & + & + & + & + & Bacillus siamensis \\
\hline WCS3-C1 & + & + & - & - & + & - & - & + & + & + & + & - & - & - & + & - & + & + & Pseudomonas otidis \\
\hline WCS3-C2 & - & + & + & - & + & - & - & + & - & - & + & + & - & - & + & - & + & + & Bacillus neizhouensis \\
\hline WCS3-C3 & + & + & - & - & - & + & - & + & - & - & - & + & - & + & + & + & + & + & $\begin{array}{ll}\text { Lysine } & \text { bacillus } \\
\text { massiliensis }\end{array}$ \\
\hline WCS3-C4 & - & - & - & - & - & + & - & + & + & + & - & - & - & - & + & + & + & + & Paenibacillus polymyxa \\
\hline WCS4-C1 & + & - & - & - & + & + & - & + & + & - & - & - & - & - & + & - & - & + & Buttiauxella ferragutiae \\
\hline WCS4-C2 & + & - & - & - & - & + & - & + & - & - & - & - & - & - & + & - & - & + & Obesumbasterum proteus \\
\hline WCS4-C3 & + & + & - & - & - & - & - & + & - & + & - & - & - & - & + & - & + & + & Bacillus horneckiae \\
\hline WCS4-C4 & - & - & - & - & - & - & - & - & - & - & - & + & - & - & - & - & + & + & Viridibacillus neidei \\
\hline WCS4-C5 & + & + & - & - & - & - & - & - & - & - & - & - & - & - & - & - & + & + & Bacillus acidiceler \\
\hline WCS5-C1 & - & - & - & - & - & - & - & + & - & - & - & - & - & - & + & - & + & + & $\begin{array}{l}\text { Corynebacterium } \\
\text { pseudodiphtheria }\end{array}$ \\
\hline WCS5-C2 & + & + & + & - & + & - & - & - & - & - & - & - & - & - & - & - & + & + & $\begin{array}{l}\text { Corynebacterium } \\
\text { matruchotii }\end{array}$ \\
\hline WCS5-C3 & - & + & + & - & - & - & - & - & - & - & - & - & - & - & - & - & + & - & Avibacterium gallinarum \\
\hline WCS6-C1 & + & - & + & - & + & - & - & - & - & - & - & + & - & - & + & - & - & - & Allivibrio fischeri \\
\hline WCS6-C2 & - & - & + & - & - & & - & + & + & - & - & - & - & - & - & + & + & - & Bacillus vietnamensis \\
\hline WCS6-C3 & - & + & + & - & + & & - & - & - & - & - & - & - & - & - & - & + & . & $\begin{array}{l}\text { Aneurinibacillus } \\
\text { aneurinilyticus }\end{array}$ \\
\hline WCS6-C4 & - & + & + & - & + & & - & - & - & - & - & + & - & - & - & - & + & + & Lactobacillus ceti \\
\hline
\end{tabular}


Fig.2 Lipase Producing Bacterial Isolates Showing Zone of Clearance

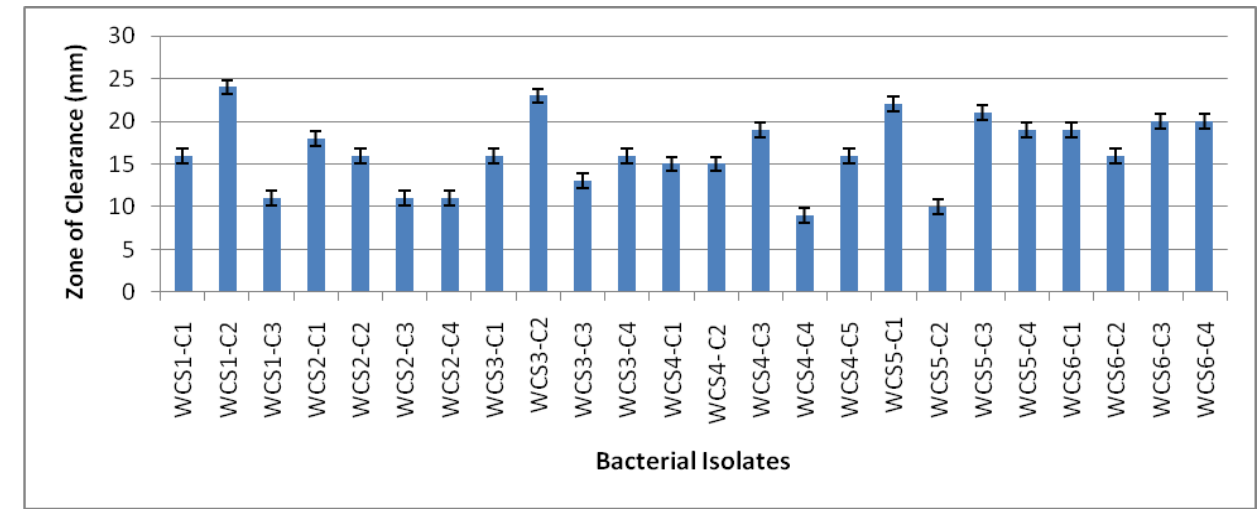

Lipases form an important group of enzymes in biotechnology with a wide range of applications in food, dairy, detergents, textile and some other industries, which are produced by microorganisms, and especially bacteria. Bacillus, Pseudomonas, and Burkholderia are the most important lipase producing bacteria (Gupta et al., 2004). However, many researches are on going to introduce new bacterial sources of lipases, and use lipases as the biocatalysts in different industries (Cristian Ruiz et al., 2004). Amongst, the lipases of B. subtilis and B. megaterium are small extracellular enzymes and classified to the subfamily 1.4 of bacterial lipases, based on amino acid sequence similarity (Travers,et al.,1987). The subfamily 1.4 lipases are mesophilic, have $\mathrm{pH}$ optima in a neutral to alkaline range $(\mathrm{pH}$ 7-11), and preferentially hydrolyze substrates with medium or shortchain fatty acids (Travers, et al.,1987). Staphylococcus is the genera shown the potential of lipase production. Staphylococcal lipases are classified as true lipases (Jaeger et al., 1999; Rosenstein and Gotz, 2000; Simons et al., 1996). In the present study, based on the zone of clearance Staphylococcus $\left(\mathrm{WCS}_{1} \mathrm{C}_{2}\right)$ and Pseudomonas $\left(\mathrm{WCS}_{3} \mathrm{C}_{2}\right.$ ) genus were found to be the highest lipase producers. The two highest lipase producing isolates were further characterized by 16SrDNA sequencing identification they are classified as Staphylococcus saprophytics and Pseudomonas otidis.

Molecular techniques utilizing amplification of target DNA provide alternative methods for diagnosis and identification (Veerapagu et al., 2014). Khataminezhad M Reza et al 2014 identified Bacillus megaterium 37-1, Bacillus safensis 1-1, Bacillus pumilus $\mathrm{KN}-$ Lip2, Bacillus subtilis KN-Lip3, and Lysinibacillus fusiformis $\mathrm{KN}-\mathrm{Lip} 4$ using $16 \mathrm{~S}$ rDNAs sequencing.

The isolates $\mathrm{WCS}_{1} \mathrm{C}_{2} \quad$ (Stapylococcus saprophyticus), $\quad \mathrm{WCS}_{3} \mathrm{C}_{2}$ ( Pseudomonas otidis), $\mathrm{WCS}_{5} \mathrm{C}_{1}$ (Corynebacterium xerosis), $\mathrm{WCS}_{5} \mathrm{C}_{3}$ (Corynibacterium matruchotii) and $\mathrm{WCS}_{6} \mathrm{C}_{4}$ (Lactobacillus ceti) were the best lipase producers. The two best lipase producers were further characterized by $16 \mathrm{~s}$ rDNA technology and identified as Staphylococcus saprophytics and Pseudomonas otidis. These bacterial strains can be used for the production of lipase enzyme for industrial applications.

\section{References}

Bajpai P. (1999) Application of enzymes in the pulp and paper industry. Biotechnology Progress, 15: 147-157 
Barrow GI, Feltham R KA.(1993). Cowan and Steel's manual for the identification of medical bacteria, $3^{\text {rd }}$ ed, Cambridge: Cambridge University press.

Brockerhoff, H and Jensen R.G.(1974) Lipolytic Enzymes. Academic Press, New York.

Claus D, Berkeley RCW. Genus Bacillus Cohn 1872. In: Sneath PHA, Mair N S, Sharpe N E, Holt JG, editors.(2011) Bergey's manual of Systemic Bacteriology. Williams and Wilkins; Baltimore: pp.1105-1139

Cristian Ruiz, Serena Falcocchio, Entela Xoxi, FI Javier Pastor, Pilar Diaz, Luciano Saso Activation and inhibition of Candida rugosa and Bacillus-related lipases by saturated fatty acids, evaluated by a new colorimetric microassay. Biochimica et Biophysica Acta (BBA)-General Subjects 1672(3), 184-191.

Cristian Ruiz; $\quad$ Ana Blanco,; F.I.Javier

Pastor and; Pilar Diaz(2002) Analysis of Bacillus megaterium lipolytic system and cloning of LipA, a novel subfamily I.4 bacterial lipase. FEMS Microbiology Letters, 217( 2), 263-267.

Falch E. A. and E.A Falch (1991). Industrial enzymes Developments in production and application. Biotechnol Adv. 9:643658.

Fujii T., Tatara T., Minagawa M. (1986) Studies on applications of lipolytic enzyme in detergency I. Effect of lipase from Candida cylindracea on removal of olive oil from cotton fabric. Journal of the American Oil Chemists' Soc., 63: 796-799.

Ghosh P.K., saxena R.K., Gupta R., Yadav R. P., Davidson S.(1996). Microbial Lipases: Production and applications. Sci. progress.79:119-157.

Gilbert, E.J. (1993). Enzyme. Microb. Technol., 15: 634-645.

Gupta R, Gupta N, Rathi P.(2004) Bacterial lipases: an overview of production, purification and biochemical properties.
Appl Microbiol Biotechnol, 64(6):76381.

Hasan F., Shah A. A and Hameed A (2006). Industrial applications of microbial lipases .Enzyme and Microbial Technology 39:235-251.

Higaki S., and Morohashi M, (2003) Propionibacterium acnes lipase in seborrheic dermatitis and other skin diseases and Unsei-in. Drugs under Experimental and Clinical Res., 29: 157-9

Jaeger K. E., Ransac S., Dijkstra B. W, Colson C., van Heuvel M., and Misset O (1994). Bacterial lipases. FEMS Microbiology Rev. 15: 29-63.

Jaeger K.E., Dijkstra B.W, and M.T.Reetz (1999) Molecular Biology,Three dimensional structures, and Biotechnological Applicatons of Lipases. Annual Reviewes of Microbiology. 53: 315-351.

Jayasree S. and Ranjani Balan (2012). Characterization and Bacterial Succession Studies of Garden Waste During the Windrow Composting Process at Mercy College Campus. Biochem. Cell. Arch. 12:403-413.

Khataminezhad Mohammad Reza , Nuhi Ashrafalsadat1 , Razavi Mohammad Reza , Nejadsattari Taher and Nazemi Ali(2014)Isolation and molecular identification of extracellular lipaseproducing bacillus species from soil. Annals of Biological Research, 5 (1):132-139

Kim H.K.,Choi H.J., Kim M.H., Sohn C.B., Oh T.K (2002). Expression and characterization of $\mathrm{Ca}^{+2-}$ independent lipase from Bacillus pumilus B26. Biochemistry and Biophysics Acta. 1538: 205-212.

Linko Y. Y., Lamsa M., Wu X., Uosukainen E., Seppala J.and Linko P(1998). Biodegradable products by lipase biocatalysis. J. Biotechnol. 66:41- 50.

Maia MMD. HeasleyA, Camargo de Morais MM, Melo EHM. Morais MJI. LedinhamWM (2001). Effect of culture 
conditions on lipase production by fusarium solani in batch fermentation. Bioresour tecnol. 76:23-27.

Masomian M, Rahman R, Salleh AB, Basri M (2013). A new thermostable and organic solvent-tolerant lipase from Aneurinibacillus thermoaerophilus strain HZ. Process Biochem. 48:169-75.

Noureddini H., Gao X. and Philkana R.S (2005). Immobilized Pseudomonas cepacia lipase for biodiesel fuel production from soybean oil. Bioresour Technol., 96: 769-77.

Patcha boonmahome and Wiyada mongkolthanaruk (2013). Lipase producing bacterium and its Enzyme Characterization journal of Life sciences and technologies.1(4): 196200.

Rosenstein R. and Gotz F. (2000). Staphylococcus lipases: Biochemical and molecular characterization. Biochimie. 82:1005-1014.

Russell S. Travers, Phyllis A. W. Martin, and Charles F. Reichelderfer (1987)Selective Process for Efficient Isolation of Soil Bacillus spp. Applied and Environmental microbiology, June 1987, p. 1263-1266

Seitz, E. W. 1974. Industrial Applications of Microbial Lipases: A Review. Journal of the American Oil Chemists' Society. 51: 12-16.

Sharma R., Christi Y and Banerjee U.C (2001). Production, purification, characterization and applications of lipases. Biotechnol Adv 19: 627-662.
Simons JWFA, Adams H., Cox R.C., Dekker N., Götz F .,Slotboom A.J.,Verheij H.M(1996) The lipase from Staphylococcus aureus. Expression in E.coli, large scale purification and comparission of substrate specificity to Staphylococcus hyicus. Eur J Biochem 242: 760-769.

Sirisha F., Rajasekar N. and Narasu M.L (2010). Isolation and Optimization of Lipase Producing Bacteria from Oil Contaminated soils.Adv.Bio.Res.4:249252.

Snellman E. A., Sullivan E. R. and Colwell R. R., (2002). Purification and properties of the extracellular lipase. LipA, of Acinetobacter sp. RAG-1. FEBS J., 269: 5771-5779.

Tembhukar U R., Dama Z B., Attarda N P and Zope P S (2012). Production And Characterization of Extracellular Lipases Of Staphylococcus Sp. Isolated From Oil Contaminated Soil. Trends in Biotechnology Research 1: 36-41.

Veerapagg M, Sankara Narayanan A, Jeya K.R, Alagendran S (2014). Isolation and identification of a Noval Lipase Producing Bacteria from Oil Spilled Soil, International Journal Of Innovative Research In Science Engineering And Technology. 3:18122-28

Wang Y,Srivastava KC, Shen GJ, Wang HY(1995). Thermostable alkaline lipase from a newly isolated thermophilic Bacillus strain, A30-1(ATCC 53841). J ferment Bioeng. 79: 433-8.

\section{How to cite this article:}

Shaini, V.P., and Jayasree, S. 2016. Isolation and Characterization of Lipase Producing Bacteria from Windrow Compost. Int.J.Curr.Microbiol.App.Sci. 5(5): 926-933. doi: http://dx.doi.org/10.20546/ijcmas.2016.505.097 